\title{
Investigating The Acceptance and Use of Performance Information System (SIP Bdg Juara) on Bandung City
}

\author{
Zati Woro Shabrina ${ }^{*}$, Dini Turipanam Alamanda ${ }^{2}$, and Fajar Sidiq Adi \\ Prabowo $^{3}$
}

1,2,3 Telkom University, Bandung, Indonesia

\begin{abstract}
Improving the utilization of ICT is one of many solutions proposed by The Municipal Government of Bandung to overcome urban problems. In its entirity, the concept is well-known as Bandung Smart City. There are many Smart Government programs that have been implemented in Bandung. One of them is Performance Information System of Bandung Juara or known as SIP Bdg Juara. But the acceptance of SIP Bdg Juara are relatively low. Furthermore, not all of the citizens have thoroughly understood the system. Hence, it is important to find out the acceptance of this website.

This research uses modified UTAUT 2 model which was taken from the UTAUT 2 Theory by Venkatesh et al. (2012) that consist of seven main variables; Performance Expectancy, Effort Expectancy, Social Influence, Facillitating Conditions, Hedonic Motivation, Price value, and Habit. Moreover, two moderating variables of Age and Gender were also involved. This research used SEM-PLS method to analyze the data. For the data collection, questionnaires were distributed to 400 residents living in the city of Bandung as the respondents whether they have or have not participated yet in SIP Bdg Juara website.

Finally, this study found that the most influential factor of interest in using SIP Bdg Juara website is Price Value, followed by Hedonic Motivation and then Habit in which all of those three factors have positive influence in both types of latent variables. While the variables affecting Use Behavior related to the use of SIP Bdg Juara wesite are Habit and Behavioral Intention. These findings are expected to provide valuable insights for The Government in improving the success rate of ICT-based governance programs.
\end{abstract}

Keywords: Bandung Smart City, Modified UTAUT 2, SIP Bdg Juara, Techonology Acceptance

\section{INTRODUCTION}

The urban transition due to rapid population growth has resulted in many challenges of city planning, development and operations which stimulate the emergence of new ideas (Harrison and Donnelly, 2013). Smart city is a concept created to solve the current city problems and will continue to be developed. Technology is not the only key component of the smart city concept, there are also

*Corresponding author. Email address: zwshabrina@gmail.com 
two other important components in it such as the society in terms of the creativities, diversities, and educations, as well as the supporting institutions such as the government and policies (Alawadhi et al., 2012). The relationship between the two components supported by ICT infrastucture will generate a very smart city. This can become the resource of the city sustainable development which will improve the life quality of the people (Alawadhi et al., 2012).

In Indonesia, the Smart City program has been implemented in big cities, one of them is Bandung City. Along with the rapid development of technology, Bandung tries to overcome the distance and time constraints faced by the society and government through the utilization of ICT. Ridwan Kamil as The Mayor of Bandung at Kompas.com's official website, claimed that 70 percent of problems in Bandung City have been resolved by the Smart City concept through the use of information technology or service-oriented applications (Ramdhani, 2016).

The Government of Bandung has made more than 300 applications to solve problems both in the society and internal bureaucracy, one of them is the creation of website based Assessment Information System application of Bandung Juara (SIP Bdg Juara). The presence of SIP Bdg Juara website as an implementation of the Smart Government programs which is expected to be a forum for public participation or feedbacks to assess the service performance of the sub-districts and urban village areas in Bandung. Therefore, the involvement of as many people as possible in the utilization of SIP Bdg Juara is needed in order to know if the services they receive have complied with the predetemined standards.

However, the expectations and achievements obtained from the presence of SIP Bdg Juara is still low, since there are still many people in Bandung who are not familiar with it and even do not know how to utilize it. As quoted in pikiranrakyat.com, the main constraint for people not to use SIP Bdg Juara is that not all of them know how to use it on computers and mobile devices, and there are still people who think that their inputs or criticisms will not get a response. In addition, a number of people also concern that criticizing the government will have a negative impact on them (Heriyanto, 2016).

Therefore, the researchers tried to evaluate the causes of the lack of public participation in using SIP Bdg Juara by UTAUT 2 model as the base of the research theory. This theory is one of the theoretical approaches to describe the level of acceptance and use of a technology created by Venkatesh, Thong, and Xu (2012). By considering UTAUT 2 model as the model, the research questions for technology acceptance problems as explained above are:

1. How is the influence of Performance Expectancy on Behavioral Intention?

2. How is Age moderate the influence of Performance Expectancy on Behavioral Intention?

3. How is Gender moderate the influence of Performance Expectancy on Behavioral Intention?

4. How is the influence of Effort Expectancy on Behavioral Intention?

5. How is Age moderate the influence of Effort Expectancy on Behavioral Intention?

6. How is Gender moderate the influence of Effort Expectancy on Behavioral Intention?

7. How is the influence of Social Influence on Behavioral Intention?

8. How is Age moderate the influence of Social Influence on Behavioral Intention? 
Investigating The Acceptance and Use of Performance Information System (SIP Bdg Juara) on Bandung City

9. How is Gender moderate the influence of Social Influence on Behavioral Intention?

10. How is the influence of Facilitating Conditions on Behavioral Intention?

11. How is Age moderate the influence of Facilitating Conditions on Behavioral Intention?

12. How is Gender moderate the influence of Facilitating Conditions on Behavioral Intention?

13. How is the influence of Hedonic Motivation on Behavioral Intention?

14. How is Age moderate the influence of Hedonic Motivation on Behavioral Intention?

15. How is Gender moderate the influence of Hedonic Motivation on Behavioral Intention?

16. How is the influence of Habit on Behavioral Intention?

17. How is Age moderate the influence of Habit on Behavioral Intention?

18. How is Gender moderate the influence of Habit on Behavioral Intention?

19. How is the influence of Behavioral Intention on Use Behavior?

This study used a multivariate analysis technique (Structural Equation Modeling) which is a method of quantitative statistical analysis which allows researchers to test more than two variables simultaneously (Indrawati, 2015). Primary data collection was done in two ways, namely by spreading online and printed questionnaires to 400 respondents. While the secondary data was obtained through literature studies, journals, research results, articles, internet, and other media information related to the research topic.

\section{LITERATURE STUDY}

\subsection{Research-Related Theory}

\subsubsection{Smart City}

A smart city is the city which invests in human and social capital, supported by ICT infrastructure and transportation to foster sustainable economic growth and quality of life improvement while maintaining the environment through participatory governance simultaneously (Caragliu et al., 2011). A city conducting advanced developments in economy, society, government, mobility, environment, and life through an ingenious combination of grants and activities convincingly and independently with the citizen awareness (Giffinger et al., 2007).

\subsubsection{Smart Government}

Smart government is one of the basic elements of a smart city. In general, smart government is a term referring to the effective implementation of ICT for public services by the government. In addition to covering government administration, smart city also handles health services, transportation, education, and so on (GamatechnoBlog, 2015). IBM says that smart government will do more than regulate the output of economic and social systems (Nam and Pardo, 2011). Furthermore, smart government makes a dynamic interconnection among the citizens, communities, and businesses in real time to trigger growth, innovation and progress (Nam and Pardo, 2011). On the other hand, other experts conclude that smart government is an integration of technology, people, policies, practices, resources, social norms and information interacting to support the activities of the city government (Chourabi, et al., 2012)

\subsubsection{Government 3.0}


Government 3.0 is a new paradigm in government operations through providing customized public services and new jobs creatively by opening and sharing government data to public and encouraging communication and collaboration among the government departments (Ministry of Public Safety and Security Korea, 2015). Government 3.0 is a more service-oriented, competent, and transparent government aiming to pursue the citizens' happiness (Ministry of Public Safety and Security Korea, 2015). Others argue that Government 3.0 refers to the use of Information and Communication Technology (ICT) and the surrounding scientific and technological domains towards the community solutions, resource optimization and citizen welfare, through civic and corporate collaboration both locally and internationally (Information System Laboratory, 2015).

\subsubsection{Open Government}

Open government is an institutional platform of technology in which the confidential government data becomes open for public (Almazán, 2011). This is done to enable the government to collaborate with the society in making decisions for improving public services (Almazán, 2011). In an open government, the state is committed that all government agencies and service providers provide all relevant information in appropriate manners (Parycek and Sachs, 2010).

\subsubsection{UTAUT 2}

UTAUT model was one of the best models to predict the acceptance of technology and describe the users' behavior in utilizing it. (Kumar S. , 2013). UTAUT model was later developed to be UTAUT 2 model in 2012 by Venkatesh, Thong, and $\mathrm{Xu}$ by adding three new factors, such as Hedonic Motivation, Price value and Habit. It has then improved the behavioral analysis using Behavioral Intention from $54 \%$ to $74 \%$ and the use of technology from $40 \%$ to $52 \%$. The develoment of the UTAUT 2 model has resulted in having nine variables, namely Behavioral Intention, Use Behavior, Performance Expectancy, Effort Expectancy, Social Influence, Facilitating Condition, Hedonic Motivation, Price value and Habit (Venkatesh et al., 2012). Experts point out that the UTAUT 2 model can account for up to $70 \%$ of consumer behavioral trends toward the use of information technology when viewed from the value of the resulting variance (Venkatesh et al., 2012).

The definition of each construct in this study is based on the definitions put forward by Venkatesh et al. (2003) and Venkatesh et al. (2012). A series of variable relationships forming this research framework is as follows:

\section{1) Relationship between Performance Expectancy and Behavioral Intention}

Performance Expectancy is defined as the extent to which individuals believe that the use of a system will help them to achieve maximum performance in their works (Venkatesh et al., 2003). Ajzen (1991:181) mentioned that intention is one of the motivating factors which influences behavior. Behavioral Intention indicates the extent to which a person will use a particular technology in the future (Marhaeni, 2014).

Performance Expectancy is the strongest predictor of Behavioral Intention (Venkatesh et al., 2003). It was also expressed through the study of Alkhunaizan and Love (2012), on the use of mobile commerce in Saudi Arabia, Performance Expectancy had the strongest influence on Behavioral Intention. In the context of organizational research, the same results were also expressed in the research of Pahnila et al. (2011:20) that Performance Expectancy is one of the factors having the most significant influence on Behavioral Intention. However, in 
relation with the moderating variables of Age and Gender, the research conducted by Yu (2012) proved that the influence of Performance Expectancy on Behavioral Intention is only moderated by Gender, without Age. While Al-Gahtani, Hubona, and Wang (2007) even stated that there is no significant interaction of Age and Gender on Performance Expectancy's influence on Behavioral Intention.

\section{2) Relationship between Effort Expectancy and Behavioral Intention}

Effort Expectancy is the level of ease perceived by the users in using a system (Venkatesh et al., 2003). The results of Venkatesh et al. (2003) showed that Effort Expectancy has a positive influence on Behavioral Intention. The same was expressed by Pahnila et al. (2011) stating that Effort Expectancy was one of the important factors in the acceptance of Tao Bao, Chinese eBay. Then, in the Foon and Fah's (2011) research on the study of Internet Banking adoption in Kuala Lumpur, it was stated that Effort Expectancy was one of the factors that directly affected Behavioral Intention. Regarding the relationship with the moderating variables of Age and Gender, the findings of Yu (2012:104) revealed that none of either the Age or Gender influences Effort Expectancy's influence on Behavioral Intention.

\section{3) Relationship between Social Influence and Behavioral Intention}

Social Influence is the extent to which a person perceives that other people around him or her (eg, family and friends) can influence him or her to use a certain technology (Venkatesh et al., 2012). According to the research of (Foon and Fah (2011), Social Influence has a significant influence on Behavioral Intention, it is also supported by a research conducted by Indrawati and Haryoto (2015) showing that Social Influence has a positive influence on Behavioral Intention.

According to Venkatesh et al. (2003), Social Influence is the factor determining Behavioral Intention directly. While Xu (2014) argued that Social Influence is the most important determinant of the Continuous Intention. In the relationship influenced by the moderating variables, Indrawati and Haryoto's (2015) study found that the Age variable can moderate the relationship of Social Influence variable and Behavioral Intention. Whereas the involvement of Gender moderating variable was stated by another research not to moderate that the influence of Social Influence on Behavioral Intention (Yu, 2012).

\section{4) Relationship between Facilitating Conditions and Behavioral Intention}

Facilitating Conditions are defined as the extent to which an individual believes that organizational and technical infrastructures exist to support the use of a system (Venkatesh et al., 2003). A research by Foon and Fah (2011) stated that Facilitating Conditions are the factors influencing Behavioral Intention. In the UTAUT 2 model, Venkatesh et al. (2012:162) added that the direct influence of Facilitating Conditions on Behavioral Intention is moderated by Gender and Age variables. In contrast, in Indrawati and Haryoto's (2015) study, it was found that there is no evidence to suggest that Facilitating Condition variables have a positive influence on Behavioral Intention.

\section{5) Relationship between Hedonic Motivation and Behavioral Intention}

Hedonic Motivation is defined as the pleasure or convenience derived from the use of technology, and it plays an important role in determining the acceptance and use of technology (Brown and Venkatesh, 2005 in Venkatesh et al., 2012). Furthermore, according to Venkatesh et al. (2012: 171), Hedonic Motivation is the important determinant of Behavioral Intention and considered as a more important booster than Performance Expectancy in a non-organizational context. 
It was also revealed through the research of Indrawati and Marhaeni (2015), that the use of instant messaging application in Bandung shows that Hedonic Motivation influences Behavioral Intention and also moderated by Age and Gender.

\section{6) Relationship between Price value and Behavioral Intention}

Price value means the value of the price or cost incurred by the consumer in the use of technology is in accordance with the expectations or hopes wished before using it (Venkatesh et al., 2012). According to the research of Indrawati and Marhaeni (2015), Price value has an influence on Behavioral Intention and also moderated by Age and Gender. On the other side, Kumar (2013) used the term "Price Level" to replace the term "Price value", which is defined as consumer attitudes toward a technology at a certain price level (will accept or reject), including whether the consumer is satisfied with the service at a certain price level or not, and how much money the consumers expect to be spend for the service offered. Furthermore, Kumar showed that Price Level has a negative influence on Behavioral Intention.

\section{7) Relationship between Habit and Behavioral Intention}

Habit is defined as the tendency of the consumer to use a technology automatically because of the previous learning experience which will become a habit later on (Venkatesh et al., 2012). Furthermore, the findings from a research showed that Facilitating Conditions, Hedonic Motivation, Price value, and Habit predictors of Behavioral Intention succeeded in increasing the R2 value of Behavioral Intention from $70 \%$ to $74 \%$ (Venkatesh et al., 2012). Research by Indrawati and Marhaeni (2015) found that the Age and Gender variables can moderate the relationship of Habit variable and Behavioral Intention.

\section{8) Relationship between Behavioral Intention and Use Behavior}

According to $\mathrm{Wu}$ et al. (2012), Use Behavior measures the actual use frequency of a technology by the users. Use Behavior is defined as the Use Behavior measured from the actual frequency of a particular technology use (Venkatesh et al., 2003). Research by Indrawati and Marhaeni (2015) found that Use Behavior variable has a positive and significant influence on Behavioral Intention. The UTAUT 2 model by Venkatesh et al. (2012), stated that the influence of Use Behavior is determined by Behavioral Intention variable. In the study of Wu et al. (2012), it was found that Behavioral Intention is one of the variables having an influence on Use Behavior. This is followed by a research of Indrawati and Marhaeni (2015) which found that Behavioral Intention variable has an influence on Use Behavior.

\section{9) Relationship between Facilitating Condition and Use Behavior}

Based on UTAUT model formulated by Venkatesh et al. (2012), Use Behavior is determined by two factors, namely Facilitating Conditions and Behavioral Intention. In the study by $\mathrm{Wu}$ et al. (2012), Facilitating Condition variables were found to positively affect Behavioral Intention variable, and their relationship is moderated by Age and Experience variables. The results are also supported by the research of Indrawati and Marhaeni (2015) which stated that both variables have positive influences moderated by Age variable. 
Investigating The Acceptance and Use of Performance Information System (SIP Bdg Juara) on Bandung City

\section{0) Relationship between Habit and Use Behavior}

In the UTAUT 2 model, the influence on Use Behavior is also determined by the Habit factor, in which Venkatesh et al. (2012) found that older men with more experienced use of technology tend to be more accustomed to using technology. Pahnila et al. (2011) conducted a study on the adoption of Chinese eBay using the term "Actual Use" instead of Use Behavior found that Habit has a significant influence on Actual Use.

\subsection{HYPOTHESES DEVELOPMENT}

The framework of this research refers to the modified UTAUT 2 model used by Indrawati and Marhaeni (2015). The differences between this study and Venkatesh et al's. (2012) are: 1) This study added the relationship between Facilitating Conditions and Use Behavior moderated by Age, and the result indicated that there is a positive and significant influence in the relationship; 2) This study used only the moderating variables of Age and Gender. Meanwhile, the moderating variable of Experience was not included since the operation of Experience variable requires the post-training period which is a length of time after the start of a system to be available for use, i.e 1 month; and 3 months (Venkatesh et al., 2003), and there was no post-training done in this research.

A previous research on the use of technology in classroom learning also used only Age and Gender as the moderating variables and the two variables were able to increase the $\mathrm{R}^{2}$ value of Behavioral Intention and Use Behavior (Alkhunaizan and Love, 2012). Another reason why this study did not involve the Experience moderator in the model is because this research includes cross sectional research. Therefore, this study as a whole uses nine major variables and two moderating variables. The conceptual framework used in this study is shown in the following figure:

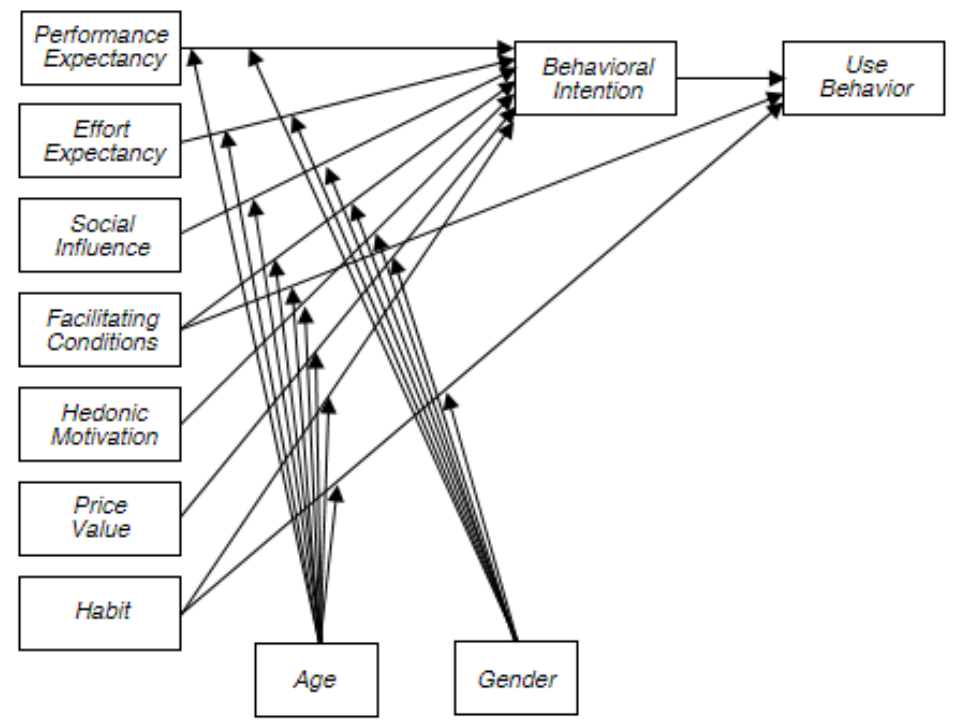

Figure 1 Conceptual Framework Modified from: Venkatesh, Thong, \& Xu (2012) 
Hypothesis is a temporary answer to the formulation of research problems (Sugiyono, 2016). It is called temporary because the answer given is based on the relevant theory, and it has not been based on empirical facts obtained through data collection. The hypothesis can be defined as a logically expected relationship between two or more variables expressed in the form of a testable statement. The relationship is estimated based on the network association specified in the theoretical framework formulated for the research study (Sekaran, 2011:135).

Based on the theories and results of the previous researches, the hypotheses used in this research are as follows:

Table 1 Hypotheses

\begin{tabular}{|c|c|}
\hline No. & Hypotheses \\
\hline H1 & Performance Expectancy has a positive and significant influence on Behavioral Intention. \\
\hline H1a & The influence of Performance Expectancy on Behavioral Intention is moderated by Age. \\
\hline H1b & $\begin{array}{l}\text { The influence of Performance Expectancy on Behavioral Intention is moderated by } \\
\text { Gender. }\end{array}$ \\
\hline H2 & Effort Expectancy has a positive and significant influence on Behavioral Intention. \\
\hline H2a & The influence of Effort Expectancy on Behavioral Intention is moderated by Age. \\
\hline H2b & The influence of Effort Expectancy on Behavioral Intention is moderated by Gender. \\
\hline H3 & Social Influence has a positive and significant influence on Behavioral Intention \\
\hline H3a & The Influence of Social Influence on Behavioral Intention is moderated by Age. \\
\hline H3b & The Influence of Social Influence on Behavioral Intention is moderated by Gender. \\
\hline H4 & Facilitating Conditions have a positive and significant influence on Behavioral Intention. \\
\hline H4a & The influence of Facilitating Conditions on Behavioral Intention is moderated by Age. \\
\hline H4b & The influence of Facilitating Conditions on Behavioral Intention is moderated by Gender. \\
\hline H5 & Hedonic Motivation has a positive and significant influence on Behavioral Intention. \\
\hline H5a & The influence of Hedonic Motivation on Behavioral Intention is moderated by Age. \\
\hline H5b & The influence of Hedonic Motivation on Behavioral Intention is moderated by Gender. \\
\hline H6 & Price value has a positive and significant influence on Behavioral Intention. \\
\hline H6a & The influence of Price value on Behavioral Intention is moderated by Age. \\
\hline H6b & The influence of Price value on Behavioral Intention is moderated by Gender. \\
\hline H7 & Habit has a positive and significant influence on Behavioral Intention. \\
\hline H7a & The influence of Habit on Behavioral Intention is moderated by Age. \\
\hline H7b & The influence of Habit on Behavioral Intention is moderated by Gender. \\
\hline H8 & Facilitating Conditions have a positive and significant influence on Use Behavior. \\
\hline H8a & The influence of Facilitating Conditions on Use Behavior is moderated by Age. \\
\hline H9 & Habit has a positive and significant influence on Use Behavior. \\
\hline H9a & The influence of Habit on Use Behavior is moderated by Age. \\
\hline H9b & The influence of Habit on Use Behavior is moderated by Gender. \\
\hline H10 & Behavioral Intention has a positive and significant influence on Use Behavior. \\
\hline
\end{tabular}




\section{RESEARCH METHODOLOGY}

This research used quantitative method. The purpose of the quantitative research is to determine exactly whether the null hypothesis is accepted and the alternative hypothesis can be rejected or otherwise (Indrawati, 2015:184). Based on its purpose, this research can be classified into a descriptive research which is usually done when the researchers have already known the factors or variables to measure an object or field, but they have not yet known the relationship among the factors or variables (Indrawati, 2015:115). According to Sekaran (2007:159), the purpose of a descriptive study is to provide the researchers with a history or description of aspects relevant to the phenomenon from the perspective of a person, organization, industry, or the other.

The type of investigation in the design of this study is the causal one. A causal research is done if the researchers want to describe the cause of a problem, whether it is carried out through experiments or non-experiments (Indrawati, 2015: 117). In this study, the involvement of the researchers is limited by not interfering with data. It means that the researchers do not provide any intervention towards the variables to be measured. The researchers directly collect data and measure the independent variables toward the dependent ones (Indrawati, 2015:118).

The unit of analysis refers to the level of data units collected during the data analysis stage (Sekaran, 2007:173). In this case, the unit of analysis is individual. Data was collected in one period, then it was processed, analyzed and then drawn in conclusion. Hence, this research used cross-sectional method (Indrawati, 2015:118). Indrawati (2015:117) mentioned that research design based on the study setting can be divided into two, namely the contrived setting and the non-contrived one. This study belongs to the non-contrived setting, which means that this research was conducted in a normal environment without any manipulation or intervention from researchers (Indrawati, 2015:117).

Data collection method in this study involves the primary and secondary data. According to Sekaran and Bougie (2010:180), primary data refers to the information gained first-hand by researchers related to the interest variables for specific study purposes. The primary data collection method used was through distribution of questionnaires. According to Sujarweni (2015:94), questionnaire is a data collection technique done by giving a set of questions to be answered. The primary data collection was conducted in April 2017. It was done by distributing the questionnaires in two ways: online questionnaires and printed questionnaires. The online distribution was carried out through instant applications and social media networks to the people living in Bandung City. While printed questionnaire was distributed by visiting public venue, such as city squares or city parks.

On the other side, the secondary data collection which refers to information collected from the existing sources (Sekaran and Bougie, 2010:180) was held through the studies of literatures, journals, research results, articles, internet, and other media related to the research topic.

In this study, the researchers used non-probability sampling technique since the exact number of population associated with the daily use of SIP Bdg Juara was not known, therefore the chances of the population members in using the application are not known whether equal or not. More specifically, the type of nonprobability sampling technique used in this study is the purposive sampling. According to Zikmund, Babin, Carr, and Grifin (2010: 396), the purposive sampling is a nonprobability sampling technique in which certain individuals are 
selected as the samples based on the conformity of required characteristics. The characteristics or criteria set by the writers for this study samples are:

1) Citizens that registered and reside on Bandung City; and

2) Aged that range from 15 to 60 years old

This study used Age as the moderating variable and it was divided into two categories; young Age and old Age. According to the United Nations (UN), the category of young Age is represented by the Ages of 15-24 years old, while the Ages above 24 years old are categorized as old Age. Therefore, this study considered the Ages of 15 - 24 years old as the category of young Age, while the Ages above 24 years old is categorized as old Age.

\section{RESULTS}

The characteristics of respondents in this study are seen from two aspects, such as Gender and Age. Viewed from Gender, $45 \%$ of the respondents were male and $55 \%$ were female. Based on Age, $80 \%$ of the respondents belonged to the Young category (young Age) and 20\% are classified as Old (old Age). Out of the 400 respondents, 169 have accessed the SIP Bdg Juara website and 39 respondents said that the Website is "Very Good", 135 respondents stated "Good", 52 respondents stated "Good enough", and 5 respondents stated "Not Good".

\subsection{Test Results of the Measurement Model (Outer Model)}

Evaluation of the measurement models with reflective variables in PLS can be started by looking at the value of Indicator Reliability which is the magnitude of the variance of the indicators to explain the latent variable. The test results of Indicator Reliability are said to be reliable if the Indicator Loading value is more than 0.7. Out of all the indicators tested, twenty-five are considered reliable. Here is the test design of the research measurement model in Figure 2, in which the Indicator Loading value of each variable can also be seen in the picture.

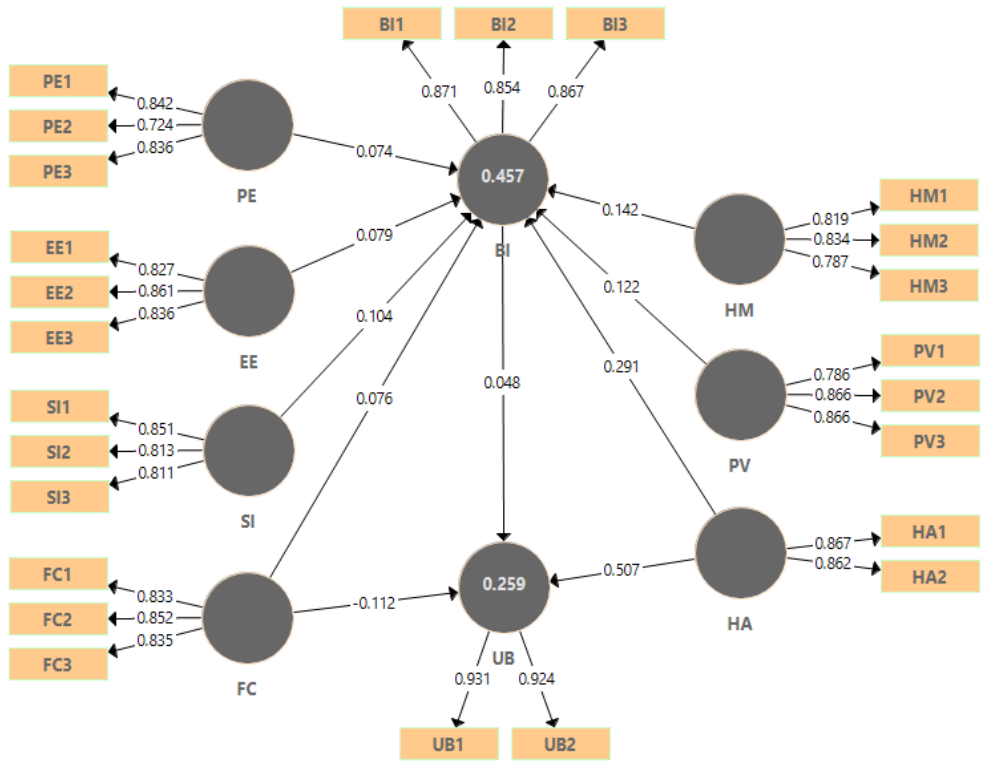

Figure 2 Outputs of the Outer Model from Smart PLS 3.0 
For Performance Expectancy variable, the indicators are PE1, PE2, and PE3 with the values of $0.842 ; 0.724$; and 0.836 . The three indicators of the Effort Expectancy variable are declared reliable with EE1 value of 0.827; EE2 of 0.861; and EE3 of 0.836, while the indicators of Social Influence variable are SI1: 0.851, SI2: 0.134, and SI3: 0.811. Furthermore, Facilitating Conditions variables have three indicators which are FC1, FC2, and FC3 with each value of $0.833 ; 0.852$; And 0.835. In Hedonic Motivation variable, the values of the indicators are 0.819 for HM1, 0.834 for HM2, and 0.787 for HM3. Price value's indicators are of PV1 equal to 0.786; PV2 of 0.861; And PV3 of 0.866. Then, the Habit variable with HA1 and HA2 indicators have the loading indicator values of 0.867 and 0.862 . And for the endogenous latent variables, Behavior Intention with the indicators of BI1, $\mathrm{BI} 2$, and $\mathrm{BI} 3$ respectively valued of $0.871 ; 0.854$; and 0.867 . Then, the last variable of Use Behavior is also declared reliable, with the indicators: UB1 and UB2 have the values of 0.931 and 0.924 .

Switching to the measurement of the second outer model, composite reliability which is used as the benchmark of variable reliability as a whole. The value of the rule of thumb used as the standard analysis is 0.70 , so the variables used were declared reliable (Garson, 2016) because their respective values are above 0.70. Performance Expectancy has a value of 0.844. Effort Expectancy and Social Influence obtain 0.879 and 0.865 . The Facilitating Condition variables have a value of 0.878. Furthermore, Hedonic Motivation, Price value, and Habit each gets 0.854 ; 0.878; and 0.855. Behavioral Intention is worth of 0.898 , and Use Behavior gets the value equal to 0.925 .

The next measurement stage is convergent validity. This stage focuses on the value of AVE (Average Variance Extracted) which should be 0.5 or greater, which means that a variable can explain the indicators well (Hair et al., 2014). Variable of Performance Expectancy has a value of 0,644. Effort Expectancy has an AVE value of 0.708. Social Influence and Facilitating Conditions variables obtained 0.681 and 0.706. Hedonic Motivation, Price value, and Habit each has the AVE values of 0.662; 0.706; and 0.747. Furthermore, Behavioral Intention got a value of 0.747 , and Use Behavior has an AVE value of 0.861 . So it can be concluded that the nine variables in this study have values above 0.5 , meaning that they can explain the indicators well.

The criterion used in the discriminant validity stage is the Average Variance Extracted (AVE) square root which must be higher than the correlation between the latent variable and the value in the AVE column (Hair et al., 2014). Variable of Performance Expectancy has the value $\sqrt{A V E}$ value of 0.80234 . Effort Expectancy is worth 0.84142 and Social Influence gets the value equal to 0.82552 . On the other side, Facilitating Conditions, Hedonic Motivation, and Price value

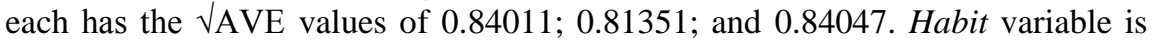
worth 0.8644. Furthermore, Behavioral Intention and Use Behavior respectively get the values of 0.86423 and 0.9277 . So it can be concluded that the overall Variable in this study is valid because each of their $\sqrt{A V E}$ value is greater than the value of AVE.

\subsection{Test Results of Structural Model Tests (Inner Model)}

The R-square adjusted ( $R^{2}$ adj) value is used to assess the accuracy level of endogenous latent variables. In the inner model tests of PLS, the $\mathrm{R}^{2}$ Adjusted ( $\mathrm{R}^{2} \mathrm{adj}$ ) criteria are used, as Hair et al. (2014) recommended the use of $\mathrm{R}^{2} \mathrm{adj}$ as the 
determinant to avoid bias. Therefore, the values of $\mathrm{R}^{2}$ and $\mathrm{R}^{2}$ adj for each endogenous latent variable in this study is as the following: Behavioral Intention variable has the $\mathrm{R}^{2}$ adj value of 0.447 , which means the endogenous latent variable of Behavioral Intention is influenced by Performance Expectancy, Effort Expectancy, Social Influence, Facilitating Condition, Hedonic Motivation, Price value, and Habit for $44.7 \%$ while the rest $55.3 \%$ is affected by other variables outside of this study. In addition, the endogenous latent variable of Use Behavior is $25.3 \%$ influenced by Behavioral Intention, Facilitating Condition, and Habit while the remaining $74.7 \%$ is influenced by other variables outside of this study.

In this study, the $\mathrm{Q}^{2}$ or Predictive Relevance has a value of 0.598 or $59.8 \%$. So, it can be concluded that the model in this study can explain the data through Behavioral Intention and Use Behavior influenced by the other variables at $59.8 \%$. The inner model (path diagram) in this study is shown in Figure 3 below.

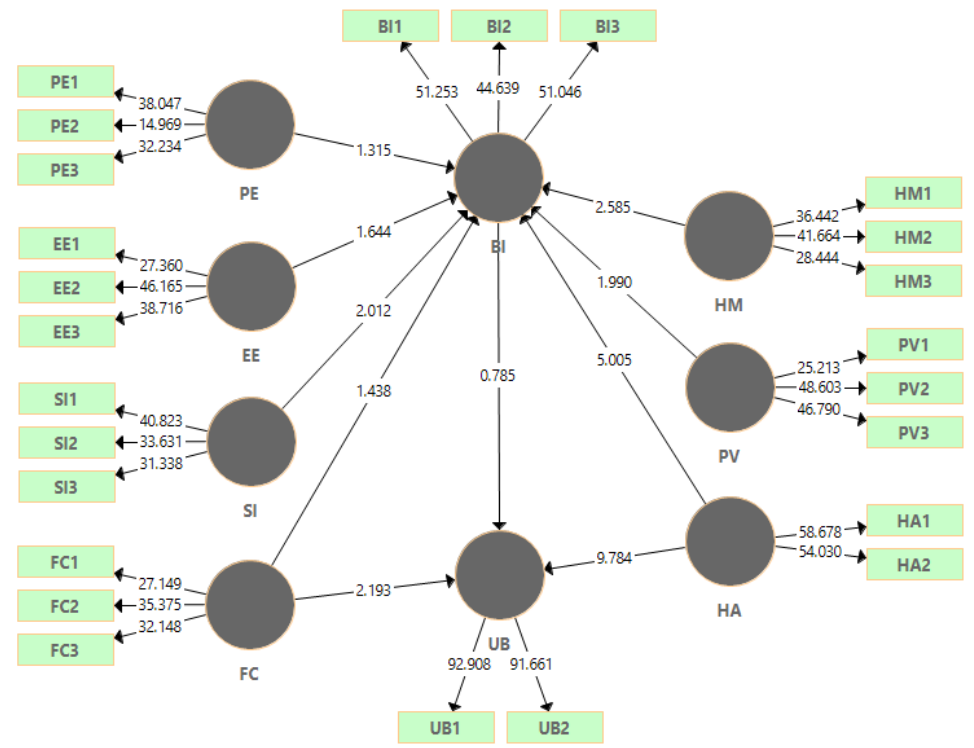

Figure 3 Outputs of the Outer Model from SmartPLS 3.0

\subsection{Hypotheses Tests}

Hypothesis tests on the effect of exogenous latent variable and endogenous latent variable in this study use one-tailed test with 5\% error rate. Therefore, the critical value to be met by the error rate is 1.645 . It means, if the value of t-statistics or t-value is greater than 1.645, then there is a significant influence between the endogenous latent variable and the exogenous latent variable being tested. In addition, the positive or negative influences of the endogenous and exogenous latent variables are observed from the value of the path coefficient (original sample). If the value of the path coefficient indicates a positive value, then the distance between the Variables is positive, whereas if the path coefficient value indicates a negative value, then the distance between the variables is negative. Moreover, there are other criteria regarding the hypothesis tests as described below:

1) If t-statistics>t-table, which is greater than 1.645 then $\mathrm{H}_{0}$ is rejected;

2) If t-statistics $\leq \mathrm{t}$-table, which is smaller than 1.645 then $\mathrm{H}_{0}$ is accepted. 
Investigating The Acceptance and Use of Performance Information System (SIP Bdg Juara) on Bandung City

As the hypotheses test to examine the influence of exogenous and endogenous latent variables in this study used a one-tailed test with an error rate of $5 \%$, therefore, the critical value must be met for the error rate is 1.645 .

Table 2 Hypothesis Test Results

\begin{tabular}{llllll}
\hline Hypothesis & Relation & $\begin{array}{c}\text { Path } \\
\text { Coefficient }\end{array}$ & t-Statistics & t-Table & Conclusion \\
\hline $\mathrm{H} 1$ & $\mathrm{PE} \rightarrow \mathrm{BI}$ & 0.048 & 0.785 & 1.645 & $\mathrm{H}_{0}$ accepted \\
$\mathrm{H} 2$ & $\mathrm{EE} \rightarrow \mathrm{BI}$ & 0.079 & 1.644 & 1.645 & $\mathrm{H}_{0}$ accepted \\
$\mathrm{H} 3$ & $\mathrm{SI} \rightarrow \mathrm{BI}$ & 0.076 & 1.438 & 1.645 & $\mathrm{H}_{0}$ accepted \\
$\mathrm{H} 4$ & $\mathrm{FC} \rightarrow \mathrm{BI}$ & -0.112 & 2.193 & 1.645 & $\mathrm{H}_{0}$ accepted \\
$\mathrm{H} 5$ & $\mathrm{HM} \rightarrow \mathrm{BI}$ & 0.291 & 5.005 & 1.645 & $\mathbf{H}_{0}$ rejected \\
$\mathrm{H} 6$ & $\mathrm{PV} \rightarrow \mathrm{BI}$ & 0.507 & 9.784 & 1.645 & $\mathbf{H}_{0}$ rejected \\
$\mathrm{H} 7$ & $\mathrm{HA} \rightarrow \mathrm{BI}$ & 0.142 & 2.585 & 1.645 & $\mathbf{H}_{0}$ rejected \\
$\mathrm{H} 8$ & $\mathrm{FC} \rightarrow \mathrm{UB}$ & 0.074 & 1.315 & 1.645 & $\mathrm{H}_{0}$ accepted \\
$\mathrm{H} 9$ & $\mathrm{HA} \rightarrow \mathrm{UB}$ & 0.122 & 1.99 & 1.645 & $\mathbf{H}_{0}$ rejected \\
$\mathrm{H} 10$ & $\mathrm{BI} \rightarrow \mathrm{UB}$ & 0.104 & 2.012 & 1.645 & $\mathbf{H}_{0}$ rejected \\
\hline
\end{tabular}

The results of t-statistics on the hypotheses of $\mathrm{H} 1, \mathrm{H} 2, \mathrm{H} 3$ and $\mathrm{H} 8$ show that $\mathrm{H}_{0}$ is accepted, it means there is no significant influence of Performance Expectancy, Effort Expectancy and Social Influence on Behavioral Intention, and Facilitating Condition variable on Use Behavior. While the other hypotheses of $\mathrm{H} 4, \mathrm{H} 5, \mathrm{H} 6, \mathrm{H} 7, \mathrm{H} 9$, and $\mathrm{H} 10$ show that $\mathrm{H}_{0}$ is rejected or $\mathrm{H}_{1}$ is accepted which means that there is a significant influence of Facilitating Condition, Hedonic Motivation, Price value variables, and Habit on Behavioral Intention, and Habit and Behavioral Intention variables on Use Behavior.

\subsection{Influence of Moderating Variables Involvement}

This research uses two moderating variables which are Age and Gender. Thus, the influence of each moderator to the relationship of exogenous and endogenous latent variables will be tested. Since the tests of Performance Expectancy, Effort Expectancy and Social Influence variables on Behavioral Intention is not significant, Facilitating Condition on Use Behavior is not significant, and Facilitating Condition towards the Use Behavior has negative path coefficient value, so the relationship between the Variables is not included in the tests of moderating variables with this SmartPLS 3.0. To determine the influence of the moderators' engagement within the SmartPLS application, the measurement of the moderator variables is done by the bootstrapping method to obtain tstatistics.

Table 3 Variable Test of Age Moderator

\begin{tabular}{lllll}
\hline Hypothesis & Relation & t-Statistics & t-Table & Conclusion \\
\hline $\mathrm{H} 5 \mathrm{a}$ & $\mathrm{HM} \rightarrow \mathrm{BI}$ & 0.819 & 1.645 & $\mathrm{H}_{0}$ accepted \\
$\mathrm{H} 6 \mathrm{a}$ & $\mathrm{PV} \rightarrow \mathrm{BI}$ & 0.481 & 1.645 & $\mathrm{H}_{0}$ accepted \\
$\mathrm{H} 7 \mathrm{a}$ & $\mathrm{HA} \rightarrow \mathrm{BI}$ & 0.198 & 1.645 & $\mathrm{H}_{0}$ accepted \\
$\mathrm{H} 9 \mathrm{a}$ & $\mathrm{HA} \rightarrow \mathrm{UB}$ & 0.815 & 1.645 & $\mathrm{H}_{0}$ accepted \\
\hline
\end{tabular}


In Table 3, it is illustrated that the hypothesis test results involving the moderating variable of Age related to the influences of Hedonic Motivation, Price value and Habit on Behavioral Intention and Habit on Use Behavior show that the relationships of the variables in the hypotheses are not moderated by Age. It is explained by each t-Statistics value of $0.819,0.481,0.198$ and 0.815 which are smaller than the t-table value, which is 1.645 .

Table 4 Variable Test of Gender Moderator

\begin{tabular}{lllll}
\hline Hypothesis & Relation & t-Statistics & t-Table & Conclusion \\
\hline $\mathrm{H} 5 \mathrm{~b}$ & $\mathrm{HM} \rightarrow \mathrm{BI}$ & 0.537 & 1.645 & $\mathrm{H}_{0}$ accepted \\
$\mathrm{H} 6 \mathrm{~b}$ & $\mathrm{PV} \rightarrow \mathrm{BI}$ & 1.382 & 1.645 & $\mathrm{H}_{0}$ accepted \\
$\mathrm{H} 7 \mathrm{~b}$ & $\mathrm{HA} \rightarrow \mathrm{BI}$ & 0.749 & 1.645 & $\mathrm{H}_{0}$ accepted \\
$\mathrm{H} 9 \mathrm{~b}$ & $\mathrm{HA} \rightarrow \mathrm{UB}$ & 1.102 & 1.645 & $\mathrm{H}_{0}$ accepted \\
\hline
\end{tabular}

Table 4 shows the hypothesis test results of Gender moderator involvement on the influences of Hedonic Motivation, Price value and Habit on Behavioral Intention and Habit on Use Behavior which reveal that the relationships of the variables in the hypotheses are not moderated by Gender. This is because tStatistics values of $0.537,1.382,0.749$ and 1.102 are smaller than the t-table value, which is 1.645 .

\section{DISCUSSION}

This study examined nine variables consisting of seven exogenous latent variables (independent variables) and two endogenous latent variables (dependent variable). The nine variables consist of Performance Expectancy (PE), Effort Expectancy (EE), Social Influence (SI), Facilitating Conditions (FC), Hedonic Motivation (HM), Price value (PV), Habit (H), Behavioral Intention (BI), and Use Behavior (UB). This study also uses two moderating variables namely Age and Gender. The variables were tested using 25 items of questionnaire questions. Testing of these variables refers to t-statistics and path coefficient of the relationships of each variable to see the level of significance as well as the positive and negative influences.

Based on the result of $\mathrm{H} 1$ test, it is stated that $\mathrm{H}_{0}$ is accepted which means that the exogenous latent variable of Performance Expectancy has no positive and significant influence on the endogenous latent variable of Behavioral Intention in the context of SIP Bdg Juara website usage, this is because the path coefficient value is 0,048 and the t-statistics is declared significant for its value of 0.785 . It can be interpreted that the extent to which the residents of Bandung city believe that the use of SIP Bdg Juara website can help them in submitting complaints and aspirations have not affected their intentions and motivation in using the public services. These results are not in line with previous research by Indrawati and Marhaeni (2015), Foon and Fah (2011), Indrawati and Haryoto (2015) and Pahnila et al. (2011) which stated that there is a significant influence between the two variables, although in different research contexts.

Based on $\mathrm{H} 2$ test, it is deduced that $\mathrm{H} 0$ is accepted which means that Effort Expectancy does not positively and significantly influence Behavioral Intention in context of the use SIP Bdg Juara website in Bandung. It means that asking to use the website of SIP Bdg Juara is not determined from the ease of using the website. 
These results are in line with a research by Taiwo and Downe (2013) in which they stated that users of information systems are concerned about the ease with which the information systems are used. The complex system of apps/webs which are difficult to navigate can make a person less interested in adopting an application system or a website. However, the hypothesis test result is correctly in line with the research of Indrawati and Marhaeni (2015).

$\mathrm{H} 3$ test result showing that $\mathrm{H}_{0}$ is accepted illustrates that Social Influence has a not-positive and significant influence on Behavioral Intention in the context of SIP Bdg Juara website usage in Bandung City. This means that the influences of the people in the user's social environmrnt such as family members or friends do not specify a person's interest in using the SIP Bdg Juara website. This result does not go along with the previous researches from Indrawati and Marhaeni (2015), Foon and Fah (2011), Indrawati and Haryoto (2015) and Pahnila et al. (2011) within different research contexts stated that there was a significant influence between the two variables.

In this study, Facilitating Conditions have no positive and significant influence on Behavioral Intention in the use of SIP Bdg Juara website. It means that conditions such as the availability of devices, internet connection, or knowledge and instructions, and others do not affect the interest of Bandung city residents in using the website of SIP Bdg Juara. This is in contrast with the research by Indrawati and Marhaeni (2015) on instant messaging applications, which explained that the better the conditions that facilitate the use of a system, the higher the interest of a person to use the system/application. However, it turns out that in the context of SIP Bdg Juara website, the statement is not applicable.

In the results of this study, a fact was obtained in the $\mathrm{H} 5$ test, in which Hedonic Motivation has positive and significant influence on Behavioral Intention in the context of the use of SIP Bdg Juara website in Bandung City. It means that the higher the sense of pleasure, comfort and prestige obtained in the use of SIP Bdg Juara website, the higher the interest of Bandung society to use the website. This is relevant with the researches of Indrawati and Marhaeni (2015) and Indrawati and Haryoto (2015). The influence of Hedonic Motivation on Behavioral Intention is in accordance with the results of Xu's research (2014) which revealed that Perceived Enjoyment has a significant influence on Behavioral Intention on Social Networks Games.

H6 test result revealed that Price value in the context of the use of SIP Bdg Juara website by Bandung society positively influences their Behavioral Intention. This is because the value of the path coefficient is 0.507 and the value of t-statistics is declared significant at 9.784. This can be interpreted that the consideration of the benefits obtained from the cost incurred in using the SIP Bdg Juara website becomes one of the factors that influence a person's interest in using the website. Further research from Putra and Ariyanti (2013) explained that Price value is one of the normal assessments of each individual towards various types of decisions. It is also supported by the statement of Indrawati and Marhaeni (2015) mentioning that the greater the benefits derive from the use of a system, the greater the interest of a person to use the system.

In $\mathrm{H} 7$ test result, there is a description explaining that $\mathrm{H}_{0}$ is rejected because the value of $t$-statistics is greater than the t-table value at 1.645 . This result proves that $\mathrm{H} 7$ is accepted since Habit has a positive and significant influence on Behavioral Intention in the context of the use of SIP Bdg Juara website in Bandung 
City. It means that someone's interest in using the SIP Bdg Juara website can be determined from how often the person is accustomed to using the application. Furthermore, it was explained by Indrawati and Marhaeni (2015) that the more accustomed someone in using the website, the higher the possibility of that someone to be interested and continue to use the website.

Based on the $\mathrm{H} 8$ test, it is explained that the Facilitating Conditions have no positive and significant influence on Use Behavior in the context of the use of SIP Bdg Juara website in Bandung. This shows that conditions such as the availability of the devices, internet connection, or knowledge and instructions, and other people from the social group cannot fully support the behavior to use the SIP Bdg Juara website by Bandung society.

H9 research result proved that Habit has a positive and significant influence on Use Behavior in the context of the use of SIP Bdg Juara website in Bandung City. It has the meaning that the Habit factor is not only able to influence the interest in using the SIP Bdg Juara website, but also able to influence the Use Behavior of the website.

Based on $\mathrm{H} 10$ test, it was stated that $\mathrm{H}_{1}$ is accepted, in which Behavioral Intention has a positive and significant influence on Use Behavior in the context of the use of SIP Bdg Juara website in Bandung. It is understood that intention can influence the users not only to access the website, but also to participate in the assessment of the sub-district and urban village where they live. This is also in line with research conducted by Indrawati and Marhaeni (2015), in which they also found that the influence of Behavioral Intention on Use Behavior is significant.

\section{CONCLUSION \& RECOMMENDATIONS}

Based on the modified model of UTAUT 2, the variables influencing user to accept and use the SIP Bdg Juara website are Price value, Hedonic Motivation and Habit, since all the three factors have positive and significant influences on Behavioral Intention. The hypothesized influence on Behavioral Intention of several variables are not evident on the results. Those variables including Performance Expectancy, Effort Expectancy, Social Influence, and Facilitating Conditions. While the variables that influence Use Behavior are Habit and Behavioral Intention. However, the moderating variables of Age and Gender do not have any influence on previously mentioned relationships regarding the use of the SIP Bdg Juara website.

This research possesses some limitations. Firstly, the data was collected in one time or cross-sectional. It prohibit this research to investigate the influence of Experience as moderator in the model since periodical data collection (longitudinal) are needed to observe it. Secondly, future research must consider the proportion of respondents in each category so that the results shown will be more representative and able to describe the actual situations which can allow more specific advices to be given.

This research also suggest The Government of Bandung to optimize those three variables that possess positive and significant influence on intention to use SIP Bdg Juara website. Thereby, the government can improve the implementation of the SIP Bdg Juara website. 
Investigating The Acceptance and Use of Performance Information System (SIP Bdg Juara) on Bandung City

\section{References}

Ajzen, I. (1991, December). The Theory of Planned Behavior. Organizational Behavior and Human Decision Processes, 50(2), 179-211. doi:10.1016/0749-5978(91)90020-T

Alawadhi, S., Aldama-Nalda, A., Chourabi, H., Gil-Garcia, J. R., Leung, S., Mellouli, S., . . W Walker, S. (2012). Building understanding of smart city initiatives. 11th IFIP WG 8.5 International Conference on Electronic Government, 7443, 40-53. doi:10.1007/978-3-642-33489-4_4

Al-Gahtani, S. S., Hubona, G., \& Wang, J. (2007, December). Information Technology (IT) in Saudi Arabia: Culture and the Acceptance and Use of IT. Information \&, 44(8), 681-691. doi:10.1016/j.im.2007.09.002

Alkhunaizan, A. M., \& Love, S. (2012). What drives mobile commerce? An empirical evaluation of the Revised UTAUT Model. International Journal of Management and Marketing Academy, 2(1), 82-99. Retrieved February 13, 2017, from http://marcomacademy.co.uk/ijmma/Whatdrives-mobile-commerce-An-empirical-evaluation-of-the-revisedUTAUT-model.pdf

Almazán, R. S. (2011). The Two Door Perspective: An Assessment Framework for Open Government. JeDEM, 3(2), 66-181. Retrieved February 12, 2017, from http://www.jedem.org/index.php/jedem/article/view/67

Brown, S. A., \& Venkatesh, V. (2005, September). Model of Adoption of Technology in the Household: A Baseline Model Test and Extension Incorporating Household Life Cycle. MIS Quarterly: Management Information Systems, 29(3), 399-426. Retrieved February 12, 2017, from https://arizona.pure.elsevier.com/en/publications/model-of-adoption-oftechnology-in-households-a-baseline-model-te

Caragliu, A., Bo, C. D., \& Nijkamp, P. (2011, August 10). Smart Cities in Europe. Journal of Urban Technology, 18(2), 65-82. doi:10.1080/10630732.2011.601117

Chourabi, H., Gil-Garcia, J. R., Pardo, T. A., Nam, T., Mellouli, S., Scholl, J. H., . . . Nahon, K. (2012). Understanding Smart Cities: An Integrative Framework. 45th Hawaii International Conference on System Sciences, 2289-2297. doi:DOI 10.1109/HICSS.2012.615

Foon, Y. S., \& Fah, B. C. (2011, April). Internet Banking Adoption in Kuala Lumpur: An Application of UTAUT Model. International Journal of Business and Management, 6(4), 161-167. doi:http://dx.doi.org/10.5539/ijbm.v6n4p161

GamatechnoBlog. (2015, August 27). Smart Government Tingkatkan Kualitas Pelayanan Publik. Retrieved February 12, 2017, from GamatechnoBlog, an idea to build a better Indonesia: https://blog.gamatechno.com/smartgovernment-tingkatkan-kualitas-pelayanan-publik/ 
Garson, G. D. (2016). Partial Least Squares: Regression \& Structural Equation Models. Asheboro, North Carolina: Statistical Associates Publishing.

Giffinger, R., Fertner, C., Meijers, E., \& Kramar, H. (2007, January). Smart cities - Ranking of European medium sized sized. Retrieved February 11, 2017, from https://www.researchgate.net/publication/261367640_Smart_cities__Ranking_of_European_medium-sized_cities

Hair, J. F., Hult, G. T., Ringle, C. M., \& Sarstedt, M. (2014). A Primer on Partial Least Squares Structural Equation Modeling (PLS-SEM). California: SAGE Pubications, Inc.

Harrison, C., \& Donnelly, A. (2013). A Theory of Smart Cities. Journal of Technology, 24-37. Retrieved from http://journals.isss.org/index.php/proceedings55th/article/viewFile/1703/ 572

Heriyanto, R. (2016, September 21). Tingkat Partisipasi Warga Menilai Kinerja Pemerintahan Masih Rendah. Retrieved December 5, 2016, from Pikiran Rakyat: http://www.pikiran-rakyat.com/bandungraya/2016/09/21/tingkat-partisipasi-warga-menilai-kinerjapemerintahan-masih-rendah-380399

Indrawati. (2015). Metode Penelitian Manajemen Dan Bisnis Konvergensi Teknologi Komunikasi dan Informasi. (D. Sumayyah, Ed.) Bandung: PT Refika Aditama.

Indrawati, \& Haryoto, K. S. (2015, August 11-15). The Use of Modified Theory Acceptance and Use of Technology 2 To Predict Prospective Users' Intention in Adopting TV Streaming. Proceedings of the 5th International Conference on Computing and Informatics, ICOCI 2015, 125, 206-215. Retrieved February 19, 2017, from http://www.icoci.cms.net.my/proceedings/2015/PDF/PID125.pdf

Indrawati, \& Marhaeni, G. A. (2015). Analisis perilaku Pengguna Aplikasi Pesan Instan dengan Menggunakan Model Unified Theory of Acceptance and Use of Technology 2 di Kota Bandung. Telkom University Journal. Retrieved Mei 15, 2017, from https://www.google.co.id/url?sa=t\&rct=j\&q=\&esrc=s\&source=web\&cd $=1 \&$ cad $=$ rja\&uact $=8 \&$ ved $=0$ ahUKEwjBlfag 1 PHTAhWHuY8KHQA9B PUQFggmMAA\&url=https\%3A\%2F\%2Frepository.telkomuniversity.ac .id\%2Fpustaka\%2Ffiles\%2F65614\%2Fjurnal_eproc\%2Fanalisisperilaku-penggunaan-aplik

Information System Laboratory. (2015, June 29). What is Government 3.0? (Department of Communication and Information Systems Engineering University of The Aegean) Retrieved April 11, 2017, from Information System Laboratory: http://hraweb.aegean.gr/islab/index.php?option=com_content $\&$ view $=$ article $\&$ id $=262$ : what-isgovernment-30\&catid=35:2010-03-26-11-56-09\&Itemid $=69$ 
Investigating The Acceptance and Use of Performance Information System (SIP Bdg Juara) on

Bandung City

Kumar, S. (2013, June 6). The Moderating Factors of 3G User Acceptance Technology in Shimla (India) Using UTAUT Model. International Journal of Computer Science \& Engineering Technology (IJCSET), 4(6). Retrieved February 13, 2017, from https://pdfs.semanticscholar.org/f3bd/910add507fcc988fabda04975995e 777a2a4.pdf

Marhaeni, G. A. (2014). Analisis Perilaku Penggunaan Aplikasi Pesan Instan dengan Menggunakan Model Unified Theory of Acceptance and Use of Technolog 2 di Kota Bandung.

Ministry of Public Safety and Security Korea. (2015). Government 3.0. Retrieved April 11, 2017, from Ministry of Public Safety and and Security: http://www.mpss.go.kr/en/gov/gov/

Nam, T., \& Pardo, T. A. (2011, June 12-15). Conceptualizing Smart City with Dimensions of Technology, People, and Institutions. The Proceedings of the 12th Annual International Conference on Digital Government Research, 282-291. Retrieved ebruari 9, 2017, from https://intaaivn.org/images/cc/Urbanism/background\%20documents/dgo_2011_sm artcity.pdf

Pahnila, S., Siponen, M., \& Zheng, X. (2011). Integrating Habit into UTAUT: The Chinese eBay Case. Pacific Asia Journal of the Association for Information System, 3(2), 1-30. Retrieved February 13, 2017, from http://aisel.aisnet.org/cgi/viewcontent.cgi?article=1050\&context=pajais

Parycek, P., \& Sachs, M. (2010, March 9). Open Government - Information Flow in Web 2.0. (E. D. SA, Ed.) European Journal of ePractice, Government 2.0 - Hype, Hope, or Reality?, 57-68. Retrieved February 12, 2017

Putra, G., \& Ariyanti, M. (2013, April). Pengaruh Faktor-Faktor dalam Modified Unified Theory of Acceptance and Use of Technology 2 (UTAUT 2) terhadap Niat Prospective Users untuk Mengadopsi Home Digital Services PT. Telkom di Surabaya. Jurnal Manajemen Indonesia, 12(4), 59-76. Retrieved February 13, 2017, from http://ijm.telkomuniversity.ac.id/wp-content/uploads/2015/02/Vol.14No1.-April-2014-Pengaruh-Faktor-Faktor-dalam-Modified-UnifiedTheory-of-Acceptance-and-Use-of-Technology-2-\%E2\%80\%94Gioliano-Putra-Maya-Ariyanti.pdf

Ramdhani, D. (2016, September 2). Ridwan Kamil: Dengan "Smart City", 70 Persen Masalah di Bandung Tuntas. (C. Damanik, Editor) Retrieved February 3, 2017, from Kompas.com: http://regional.kompas.com/read/2016/09/02/14122821/ridwan.kamil.de ngan.smart.city.70.persen.masalah.di.bandung.tuntas

Sekaran, U. (2007). Research Methods for Business. Jakarta: Salemba Empat.

Sekaran, U. (2011). Research Method for Business. Jakarta: Salemba empat. 
Sekaran, U., \& Bougie, R. (2010). Research Method for Business: A Skill Building Approach. Great Britain: Wiley.

Sugiyono. (2016). Metode Penelitian: Kuantitatif, Kualitatif, dan R\&D. Bandung: Alabeta.

Sujarweni, V. W. (2015). Metodologi Penelitian Bisnis dan Ekonomi. Yogyakarta: Pustaka Baru Press.

Taiwo, A. A., \& Downe, A. G. (2013, January). The theory of user acceptance and use of technology (UTAUT): A meta-analytic review of empirical findings. Journal of Theoretical and Applied Information Technology, 49(1).

Venkatesh, V., Morris, M. G., Davis, G. B., \& Davis, F. D. (2003, September). User Acceptance of Information Technology: Toward a Unified View. MIS Quarterly, 27(3), 425-478. Retrieved February 6, 2017, from https://nwresearch.wikispaces.com/file/view/Venkatesh+User+Acceptan ce+of+Information+Technology+2003.pdf

Venkatesh, V., Thong, J. Y., \& Xu, X. (2012, March). Consumer Acceptance and Use of Information Technology: Extending the Unified Theory of Acceptance and Use of Technology. MIS Quarterly, 36(1), 157 - 178. Retrieved December 5, 2016, from http://cmapspublic2.ihmc.us/rid=1P18XSWRF-314ZND28H8/Venkatesh\%20et\%20al.\%20-\%202012\%20$\% 20$ Consumer $\% 20$ acceptance $\% 20$ and $\% 20$ use $\% 20$ of $\% 20$ information $\% 2$ Otechnol.pdf

Wu, M.-Y., Yu, P.-Y., \& Weng, Y.-C. (2012). A Study on User Behavior for I Pass by UTAUT: Using Taiwan's MRT as an Example. Asia Pacific Management Review, 17(1), 91-111. Retrieved Mei 15, 2017, from http://apmr.management.ncku.edu.tw/comm/updown/DW1204184516.p df

$\mathrm{Xu}, \mathrm{X}$. (2014). Understanding Users' Continued Use of Online Games: An Application of UTAUT2 in Social Network Games. MMEDIA 2014 : The Sixth International Conferences on Advances in Multimedia, 58-65.

Yu, C.-S. (2012). Factors Affecting Individuals to Adopt Mobile Banking: Empirical Evidence from The UTAUT Model. Journal of Electronic Commerce Research, 13(2), 104-121. Retrieved February 13, 2017, from http://www.jecr.org/sites/default/files/13_3_p01_0.pdf

Zikmund, W. G., Babin, B. J., Carr, J. C., \& Grifin, M. (2010). Business Research Methods 8th Edition. Canada: Cengage Learning. 